\title{
AEROBIC BACTERIAL MICROBIOTA IN Stomoxys calcitrans: PRELIMINARY STUDIES IN BRAZIL*
}

\author{
BRUNO G. DE CASTRO ${ }^{1}$; MILIANE M.S. DE SOUZA ${ }^{2}$; AVELINO J. BITTENCOURT ${ }^{3}$
}

\begin{abstract}
CASTRO, B.G. DE; SOUZA, M.M.S DE; BITTENCOURT, A.J. Aerobic bacterial microbiota in Stomoxys calcitrans: preliminary studies in Brazil. [Microbiota bacteriana aeróbica em Stomoxys calcitrans: estudos preliminares no Brasil]. Revista Brasileira de Parasitologia Veterinária, v. 16, n. 4, p. 193-197, 2007. Departamento de Medicina e Cirurgia Veterinária, Universidade Federal Rural do Rio de Janeiro, Km 7 da BR 465, Seropédica, RJ 23890-000, Brasil. E-mail: bittenc@ufrrj.br

The stable fly, Stomoxys calcitrans, has a great importance in medical and veterinary health due to its feeding and reproductive habits, which can disseminate some pathogenic agents among hosts even at long distances. This study aimed to describe, for the first time in Brazil, the bacterial microbiota in segments of the stable fly. Bacterial species were isolated from three different segments (cuticle, mouth parts and abdominal alimentary tract) of the stable fly. Twenty dairy farms were visited in four municipalities: Barra Mansa, Quatis, Resende and Rio Claro in the State of Rio de Janeiro in order to collect 20 flies in each site. Dissection of the flies and procedures of isolation and identification of bacterial species were performed. A total of 161 colonies of 33 distinct species were isolated, such as Escherichia coli, Staphylococcus aureus, and S. intermedius. Stomoxys calcitrans may harbor bacterial agents on their cuticle, mouth parts and abdominal alimentary tract and these bacteria may be pathogenic to their hosts.
\end{abstract}

KEY WORDS: stable fly; bacterial microbiota; cuticle; mouth parts; abdominal alimentary tract

\section{RESUMO}

A mosca dos estábulos, Stomoxys calcitrans, possui grande importância médica e veterinária devido a seus hábitos alimentares e reprodutivos, visto que pode disseminar agentes patogênicos para hospedeiros, mesmo a longas distâncias. Esse estudo teve por objetivo, pela primeira vez no Brasil, descrever a microbiota bacteriana de segmentos da mosca dos estábulos. As espécies bacterianas foram isoladas de três diferentes segmentos (superfície externa, aparelho bucal e trato digestivo abdominal) de $S$. calcitrans. Foram visitadas $20 \mathrm{fa}-$ zendas leiteiras em quatro municípios: Barra Mansa, Quatis, Resende e Rio Claro no Estado do Rio de Janeiro para coletar

\footnotetext{
* Supported by Capes.

${ }^{1}$ Curso de Pós-Graduação em Ciências Veterinárias, Universidade Federal Rural do Rio de Janeiro (UFRRJ), Km 7 da BR 465, Seropédica, RJ BR 465 Brasil, 23890-000. Bolsista Faperj Nota 10. E-mail: brunogc@ufrrj.br

${ }^{2}$ Laboratório de Bacteriologia Veterinária, Departamento de Microbiologia e Imunologia Veterinária, Instituto de Veterinária (IV), UFRRJ. E-mail: miliane@ufrrj.br

${ }^{3}$ Departamento de Medicina e Cirurgia Veterinária, IV, UFRRJ. E-mail: bittenc@ufrrj.br
}

20 moscas em cada uma delas. A dissecção das moscas e os procedimentos de isolamento e identificação bacteriana foram realizados. Um total de 161 colônias de 33 espécies distintas foi isolado, dentre elas Escherichia coli, Staphylococcus aureus e $S$. intermedius. Stomoxys calcitrans pode veicular agentes bacterianos presentes na superfície externa, aparelho bucal e trato digestivo abdominal e essas bacterias possuem potencial patogênico a diversos hospedeiros deste muscídeo.

PALAVRAS-CHAVE: mosca dos estábulos; microbiota bacteriana; superfície externa; aparelho bucal; trato digestivo abdominal

\section{INTRODUCTION}

The dipterans, particularly the flies, have great medical and veterinary importance because they use a variety of substracts for feeding and development. Usually, substracts such as human and animal fecal material, litter, and decomposing organic material are contaminated. In addition to transmission of pathogenic agents through a direct contact, hematophagous flies may ingest agents from infected animals during blood feeding, transmitting them 
in the following feeding (GRACZYK et al., 2001; OLIVEIRA et al., 2002).

Among the hematofagous flies, Stomoxys calcitrans (Linnaeus, 1758), known as the "stable fly", does not only harbors pathogenic agents but also causes great economic losses to animal production due to the pain and energy wasted by the animals in the effort to avoid the annoyance produced by the bites. Consequently, food ingestion by the hosts is diminished, resulting in weight losses and decrease in milk and meat production. In addition, weakened and infested animals become more susceptible to diseases (BITTENCOURT; MOYA-BORJA, 2002).

Regarding transmission of pathogenic agents, it has been reported that $S$. calcitrans is able to harbor a variety of agents that cause diseases in man and animals, such as viruses, bacteria, protozoan, fungi, eggs and infective larvae of helminths (PHILPOOT; EZEH, 1978; OLIVEIRA et al., 2002; KERR, 2002).

Few studies have been developed regarding the stable fly, mainly in Brazil. Greenberg (1971) reported the existence of 38 distinct species of bacteria in the stable fly. This number is lower when compared to studies carried out with Musca domestica, in which approximately 200 distinct species and subspecies of bacteria have been found. This fact can be explained by the higher frequency and synanthropism of the $M$. domestica in relation to $S$. calcitrans (GREENBERG, 1971).

The present study had the objective to carry out a survey on the bacterial microbiota of $S$. calcitrans, based on isolation and identification of the distinct species of aerobic bacteria present on the cuticle, in the mouth parts and in the abdominal portion of the alimentary tract of flies.

\section{MATERIALS AND METHODS}

The study was carried out from April to October 2003 and 20 dairy cattle farms were visited during that period. They were equally divided among four Municipalities the Vale do Paraíba Fluminense micro region as: Barra Mansa, Resende, Rio Claro and Quatis in the State of Rio de Janeiro, Brazil. These farms were selected from previous studies in this counties, where it was verified the presence of the stable fly (JULIASSE; BITTENCOURT, 2000; CASTRO et al., 2001; PIRES et al., 2003).

In each farm, 20 stable flies were collected using a previously sterilized entomological net. To avoid environment contamination, the entomological net was changed always after five flies were collected. Only flies feeding on milking cows or those flying at a maximum distance of $50 \mathrm{~cm}$ from the host were collected, as recommended by Bramley et al. (1985). The collected flies were placed into sterile tubes labeled with the date, name of the farm and county, and kept under refrigeration until sent to the Laboratório de Bacteriologia do Departamento de Microbiologia e Imunologia Veterinária, Instituto de Veterinária, Universidade Federal Rural do Rio de Janeiro.
In the laboratory, the flies were dissected under a stereoscopic microscope inside a laminar flow hood and close to the Bunsen fire. In order to evaluate the microbiota on the cuticle, the flies were placed into Brain Heart Infusion (BHI, Merck) medium and stirred for two minutes. The flies were removed from the medium and then placed into another tube containing alcohol $70^{\circ} \mathrm{GL}$, during two minutes, as recommended by Hillerton and Bramley (1985), for sterilization of their cuticles.

After that, the flies had their head separated from the body; subsequently the head, with proboscis and salivary glands were collected. This material was transferred to another tube containing BHI and was macerated using a sterile tube.

The abdomen was separated from the rest of the body. The last abdominal segment was detached with the abdominal alimentary tract from each fly (OLIVEIRA et al., 2002) and placed into a third tube containing BHI medium for maceration, as previously described. The resulting materials in tubes containing BHI medium were incubated for 24 hours at $37^{\circ} \mathrm{C}$.

After this period, the samples were subcultured on BHI, Phenol Red Manitol (PRM, Merck) and MacConkey (MC, Merck) Agar and incubated for 24 hours at $37^{\circ} \mathrm{C}$. Following incubation, colonies were observed for differences in morphology, size and pigment production. Predominant colony types on each plate were Gram-stained and identified by morphological characteristics, and then specific tests were performed according to the genus.

Species of Staphylococcus were identified by colony morphology on PRM agar, tube coagulase test, bacitracin resistance, maltose fermentation, Voges-Proskauer test, nitrate reduction, and urease production. Streptococcus spp. were cultured on defibrinated sheep blood agar plates and submitted to optoquin resistance, esculin, and hipurate hidrolysis. Enterobacterias were subcultured on methyleneblue-eosin agar (EMB, Merck), and following procedures of identification were performed: motility agar, TSI agar slants, Indol production, lysine and ornithine decarboxylase, phenilalanine deaminase test, Voges-Proskauer test, glucose fermentation with gas production, sugar fermentation, urease production, citrate and malonate degradation. For Corynebacterium spp., Actynomyces spp., and Bacillus spp., those species were identified by colony morphology on BHI and characterized by esculin and hipurate hydrolysis, gelatin hydrolysis, VogesProskauer test, pronounced urease activity, fermentation of sugars and nitrates reduction (KONEMAN et al., 2001).

\section{RESULTS AND DISCUSSION}

After laboratorial procedures, 161 isolates (100\%) were identified in the 400 collected flies. The majority of them, 64 isolates (39.75\%), were originated from the cuticle of collected flies, followed by the macerate from the abdominal portion dissected of the alimentary tract, with 56 colonies (34.78\%), and the macerate from the mouth parts, with 41 colonies (25.47\%). 
Table 1. Number of farms where bacterial colonies were isolated and identified and the evaluated body segment, in municipalities of the "Vale do Paraíba Fluminense" Microregion, Rio de Janeiro, Brazil.

\begin{tabular}{|c|c|c|c|c|c|c|c|c|c|c|c|c|}
\hline \multirow[t]{2}{*}{$\begin{array}{l}\text { Bacterial } \\
\text { colonies }\end{array}$} & \multicolumn{3}{|c|}{$\begin{array}{c}\text { Barra Mansa } \\
\quad(n=5)\end{array}$} & \multicolumn{3}{|c|}{$\begin{array}{l}\text { Quatis } \\
(n=5)\end{array}$} & \multicolumn{3}{|c|}{$\begin{array}{c}\text { Resende } \\
(\mathrm{n}=5)\end{array}$} & \multicolumn{3}{|c|}{$\begin{array}{c}\text { Rio Claro } \\
(\mathrm{n}=5)\end{array}$} \\
\hline & Cuticle & $\begin{array}{l}\text { Mouth } \\
\text { parts }\end{array}$ & Int. & Cuticle & $\begin{array}{l}\text { Mouth } \\
\text { parts }\end{array}$ & Int. & Cuticle & $\begin{array}{l}\text { Mouth } \\
\text { parts }\end{array}$ & Int. & Cuticle & $\begin{array}{l}\text { Mouth } \\
\text { parts }\end{array}$ & Int. \\
\hline Actynomyces spp. & & & & & & & & 2 & 3 & & & \\
\hline Bacillus cereus & 4 & 4 & 2 & 3 & 1 & 3 & 1 & 2 & 3 & 2 & 2 & 1 \\
\hline B. alvei & & & & & & & & & & 1 & & \\
\hline B. coagulans & & & & & & & & 1 & 2 & & & 1 \\
\hline B. megaterium & 1 & & & & & & & & & & & 1 \\
\hline B. subtilis & & 1 & & & & & 2 & & & 1 & & 1 \\
\hline B. thuringiensis & & & & 2 & & 1 & & & & & 1 & \\
\hline Bacillus spp. & 1 & 2 & 3 & & 1 & 1 & 2 & 3 & 3 & 2 & 1 & \\
\hline Escherichia coli & 3 & & 2 & 2 & & 1 & 2 & & & 2 & 2 & 2 \\
\hline Citrobacter diversus & & & & & 1 & & & 1 & 1 & & & \\
\hline C. amalonaticus & & & & & & & & & & & & 1 \\
\hline Enterobacter spp. & & 1 & & & 1 & & 1 & & & 2 & & \\
\hline E. aerogenes & & & & 1 & & & & & & & & \\
\hline E. cloacae & 2 & & & & & & & & & & & \\
\hline Klebsiella oxytoca & & & & & & & 1 & 1 & 1 & 1 & & \\
\hline Proteus mirabilis & & & 1 & & & 2 & & & & & & \\
\hline Proteus vulgaris & & & & 1 & & 1 & 2 & & & & & \\
\hline Providencia stuartii & 1 & & & & & & & & & & & \\
\hline Salmonella spp. & & & 1 & 2 & & & & 1 & 1 & & & 1 \\
\hline Serratia marcescens & & & & & & & & & & & & 1 \\
\hline Shigella spp. & & & & & 2 & & & & & & & \\
\hline Staphylococcuus aureus aureus & 2 & 3 & 2 & 2 & 2 & 3 & 1 & 1 & & 1 & 1 & 1 \\
\hline S. epidermidis & & & & & & & 1 & & & & & \\
\hline S. equorum & & & & 2 & & & & & & & & \\
\hline S. gallinarum & 2 & & 2 & & & 1 & & & & & & \\
\hline S. hycus & & & & & & & & & & & & 1 \\
\hline S. intermedius & & & & 1 & & & 2 & 1 & 1 & & & \\
\hline S. muscae & & & & & & & & & & 2 & & \\
\hline S. schleiferi coagulans & & & & & & 1 & & 1 & & 1 & & \\
\hline S. xylosus & & & & & & & & & & & & 1 \\
\hline Pseudomonas aeruginosa & & & & 2 & & & & & & & 1 & \\
\hline Corynebacterium spp. & & & & & & 1 & & & & & & \\
\hline Enterococcus faecalis & & & & & & & & 1 & & & & \\
\hline
\end{tabular}

M. parts stands for Mouth parts and Int. stands for abdominal portion of the digestive tube.

Data of isolation and identification of the bacterial species from the three body parts of S. calcitrans collected in the 20 farms of each municipality are presented in Table 1. Thirtythree distinct species of bacteria were identified from the 161 colonies isolated. Among them, only 14 colonies had been previously described, demonstrating the need for further studies related to the microbiota of $S$. calcitrans.

Among the highly potential pathogenic species for humans and animals, Escherichia coli, Salmonella spp., and Shigella spp. (Enterobacteriaceae) are responsible for outbreaks of enteric diseases in the world, particularly in countries where sanitary conditions are poor (BROOKS et al., 2000; GRACZYK et al., 2001).

Other species from this family, isolated and identified in the present study, are potential agents of diseases. The species Citrobacter amalonaticus, C. diversus, Proteus vulgaris and $P$. mirablis are associated with gastro-enteric disorders (BROOKS et al., 2000; KONEMAN et al., 2001).

The identification of Serratia marcescens in the abdomi- nal portion of the alimentary tract of flies collected from Rio Claro, opens the possibility of further studies to control this fly, as this bacteria is considered a pathogen for insects and may be used for a biological control of $S$. calcitrans (LYSYK et al., 2002).

The species S. a. aureus, with pathogenic potencial to man and animals, was present in almost body parts of flies collected in the four visited municipalities. Another species of the same family, S. intermedius, which is pathogenic to animals and can cause bovine mastitis, was isolated and identified in this survey.

The species S. schleiferi coagulans, observed in Quatis (abdominal portion of alimentary tract), Resende (mouth parts) and Rio Claro (cuticle), is associated with otitis in dogs (KONEMAN et al., 2001).

Another pathogenic species to animals, identified in this study, was $S$. hyicus, which can causes exudative epidermitis in pigs (NISHIFUJI et al., 2005) Considering that after blood feeding this fly rests and defecates on fences, wooden posts 
and walls, the animals raised in this locations could acquire infection through direct contact.

According to Brooks et al. (2000), the species $S$. epidermidis can potentially cause cutaneous infections in man and animals, as well as mastitis in cattle. This species was observed once on the cuticle of flies collected in Resende.

Another species from the same family associated with human diseases is the $S$. xylosus that can causes infections in the urinary tract (KONEMAN et al., 2001). This bacterium was observed in the abdominal portion of the alimentary tract from flies collected in Rio Claro.

Other three species isolated in the present study are not reported in the literature as agents that cause diseases in man or in animals. These are S. gallinarum, frequently observed in feces of gallinaceous birds; S. equorum, described in equines but with no determined pathogeny, and S. muscae, present in the transitory microbiota of muscids living in stables (SCHLEIFER et al., 1984; HÁJEK et al., 1992; KONEMAN et al., 2001).

Four colonies of S. gallinarum were identified from flies collected in Barra Mansa and Quatis. Previous studies in these locations have reported the use of poultry litter as an organic fertilizer in agriculture and also as animal food (JULIASSE; BITTENCOURT, 2000; CASTRO et al. 2001; PIRES et al., 2003).

Due to its alkalinization, the poultry litter favors the development of bacteria of the genus Staphylococcus spp (JORGE, 1997). The association of stable flies with these bacteria may be explained by the fact that the poultry litter is an excellent medium for the development of larval stages of this fly (AVANCINI, SILVEIRA, 2000).

Most species of the family Bacillaceae are considered an environmental contaminant. The species Bacillus cereus, a potential agent of food intoxication outbreaks in man and animals (KONEMAN et al., 2001), was observed in all body parts of flies originated from all locations studied.

The species $B$. thuringiensis, observed on the cuticle as well as in the mouth parts and in the abdominal portion of the alimentary tract, is described in the literature as a pathogen for insects and are also used for their biological control (JOHNSSON et al., 1998).

Other species from this genus, B. alvei, B. megaterium, $B$. subtilis and $B$. coagulans, which occasionally show clinical importance in man and animals, were observed in all body parts of stable flies. They are opportunistic pathogens, saprophytes, and are considered of low pathogenicity (KONEMAN et al., 2001).

Pseudomonas aeruginosa (Pseudomonadaceae), observed on the cuticle of flies collected in Quatis and in the mouth parts of flies collected in Rio Claro, is considered by several authors as an environmental contaminant (BROOKS et al., 2000). However, it may cause septicemia, cystitis, mastitis, genital infections, respiratory diseases, pneumonia, otitis and conjunctivitis in man and animals (KONEMAN et al., 2001).

Regarding to the family Streptococcaceae, the species Enterococcus faecalis was observed only in mouth parts from flies collected in Resende. This bacteria is frequently isolated from human biologic samples and from human intestines, being also present in the intestinal tract of domestic birds, cattle, pigs, dogs, sheeps and goats. Besides, it is considered a causal agent of the cattle bacterial mastitis (FISHER, 1999; KONEMAN et al., 2001). Taking into consideration that $S$. calcitrans is a hematofagous fly, inoculation of these pathogens into the host may occur.

Associated with the dispersion of the stable fly, the dissemination of pathogenic agents carried on its cuticle can be important. This fly can disseminate theses microorganisms to many places and materials, including food for animals. According to Schofield and Torr (2002), the stable fly rests on feeding units after blood intaking and uses food wastes for its oviposition. Therefore, flies may contaminate animal food with pathogenic agents. Thus, the stable fly has the ability to be a mechanical vector for these bacteria due to its feeding habits (interrupted feeding), as well as its great flying capacity, which may be up to $29 \mathrm{~km}$ per day (BAILEY et al., 1973). These features favor its distribution and the dissemination of pathogenic microorganisms among properties.

Another way by which the agents on the cuticle of flies can contaminate the hosts is through skin lesions, such as the micro-hemorrhages originated from bites of stable flies (BITTENCOURT, 2000). As the presence of bacteria on the cuticle of flies may contaminate these skin lesions, the habit of defecation of hematophagous dipterans associated with blood engorging, contributes to transmission of pathogenic agents that are eliminated through this via.

In addition to contamination of animal food, these flies may disseminate pathogenic agents to potential sources of food used for human consumption. This is the case of the leafy vegetables that uses decomposing organic matter residues as fertilizer, which are also used by flies for development of larvae (AVANCINI; SILVEIRA, 2000).

Similarly, propagation of agents through the mouth parts of $S$. calcitrans has great importance because this species has the habit to regurgitate during blood meal. Beyond the regurgitation, the interrupted alimentation indicates that this fly may mechanically transmit to healthy individuals pathogenic stages of some microorganisms, almost immediately after ingestion of blood from infected animals (SCHOFIELD; TORR, 2002).

The methodology used was directed for wide range isolation, using selective and enriched media, such as PRM and $\mathrm{BHI}$ respectively, aiming to allow growth of bacterial species present at low concentrations that could, otherwise, be inhibited by prevalent species. This approach offers different conditions for microbial growth, allowing higher accuracy in microbiological investigations and enabling the detection of variety of species, as observed in the present study (BROOKS et al., 2000).

In conclusion, the stable fly has the ability to carry many bacterial species in its segments, as evidenced by recovering bacterial species with high pathogenic potential. The cuticle 
was the segment from where most species were isolated, followed by abdominal digestive tract and mouth parts.

\section{REFERENCES}

AVANCINI, R.M.; SILVEIRA, G.A. Age structure and abundance in populations of muscoid flies from a poultry facility in Southeast Brazil. Memórias do Instituto Oswaldo Cruz, v. 95, n.2, p. 259-64, 2000.

BAILEY, D. L.; WHITFIELD, T. L.; SMITTLE, B. J. Flight dispersal of stable fly. Journal of Economic Entomology, v. 66, n.2, p. 410-411, 1973.

BITTENCOURT, A. J. Stomoxys calcitrans (Linnaeus, 1758): Importância econômica e estágio atual das pesquisas. Hora Veterinária, v. 21, n. 125, p. 36-40, 2002.

BITTENCOURT, A. J.; MOYA-BORJA, G.E. Stomoxys calcitrans (Linnaeus, 1758) (Diptera: Muscidae): preferência por locais do corpo de bovinos para alimentação. Revista Brasileira de Zoociências, v. 1, n. 4, p. 75-83, 2002.

BRAMLEY, A.J.; HILLERTON, J.E.; HIGGS, T.M.; HOGBEN, E.M. The carriage of summer mastitis pathogens by muscid flies. British Veterinary Journal, v. 141, n. 6, p. 618-627, 1985.

BROOKS, G. F.; BUTEL, J. S.; MORSE, S. A. Jawetz, Melnick \& Adelber: Microbiologia Médica. Rio de Janeiro: Guanabara Koogan, 2000. 524p.

CASTRO, B. G.; PIRES, S. D.; BITTENCOURT, A. J.; OLIVEIRA, A.; FLAUSINO, G.; FERNANDES, H. A. L.; AZEVEDO, F. D.; ALMEIDA, B. M. Avaliação da capacidade de transmissão de bactérias causadoras de mastite por Stomoxys calcitrans (L.) em bovinos leiteiros. Jornal Brasileiro de Patologia, v. 37, n. 4, p. 173, 2001.

FISHER, O. The importance of Diptera for transmission, spreading and survival of agents of some bacterial and fungal disease in human and animals. Veterinary Medicine, v. 44, n. 5, p. 133-160, 1999.

GRACZYK, T. K.; KNIGHT, R.; GILMAN, R. H.; CRANFIELD, M. R. The role of non-biting flies in the epidemiology of human infectious diseases. Microbes and Infection, v. 3, n. 3, p. 231-235, 2001.

GREENBERG, B. Ecology, classification and biotic association. In: GREENBERG, B. Flies and diseases. Princeton: Princeton University Press, 1971. v. 1. 856p.

HÁJEK, V.; LUDWIG, W.; SCHLEIFER, K. H.; SPRINGER, N.; ZITZELSBERGER, W.; KROPPENSTEDT, R. M.; KOCUR, M. Staphylococcus muscae, a new species isolated from flies. International Journal of Systematic Bacteriology, v. 42, n. 1, p. 97-101, 1992.

HILLERTON, J. E.; BRAMLEY, A. J. Carriage of Corynebacterium pyogenes by cattle nuisance flies Hydrotaea irritans (Fallen) and Musca autumnalis (De Geer). Veterinary Parasitology, v. 18, n. 3, p. 223-228, 1985.
JOHNSON, C.; BISHOP, A. H.; TURNER, C. L. Isolation and activity of strains of Bacillus thuringiensis toxic to larvae of the housefly (Diptera: Muscidae) and tropical blowflies (Diptera: Calliphoridae). Journal of Invertebrate Pathology, v. 71, n. 2, p. 138-144, 1998.

JORGE, M. A. Cama de Frango e Sanidade Avícola. In: CONFERÊNCIAAPINCO 97 DE CIÊNCIA E TECNOLOGIA AVÍCOLAS. 1997, São Paulo, Anais... Campinas: Facta, 1997, p. 52.

JULIASSE, M. A. M.; BITTENCOURT, A. J. Aspectos clínico-epidemiológicos de Stomoxys calcitrans em bovinos e eqüinos em propriedades rurais de diferentes áreas fisiográficas do estado do Rio de Janeiro. In: JORNADA DE INICIAÇÃO CIENTÍFICA, 10, 2000, Seropédica. Anais... Seropédica: UFRRJ, 2000. v.10, p. 209-210.

KERR, C. Bloodsucking fly blamed for transmitting HIV. Lancet Infectious Diseases, v. 2, n. 5, p. 265, 2002.

KONEMAN, E. W.; JANDA, S. D.; SCHRECKENBERGER, W. M.; WINN JR, P. C. Diagnóstico Microbiológico Rio de Janeiro: MEDSI, 2001. 1204 p.

LYSYK, T. J.; KALISCHUK-TYMENSEN, L.D.; SELINGER, L. B. Comparsion of selected growth media for culturing Serratia marcescens, Aeromonas sp., and Pseudomonas aeruginosa as pathogens of adult Stomoxys calcitrans (Diptera: Muscidae). Journal of Medical Entomology, v. 39, n. 1, p. 89-98, 2002.

NISHIFUJI, K.; FUDABA, Y.; YAMAGUCHI, T.; IWASAKI, T.; SUGAI, M.; AMAGAI, M. Cloning of swine desmoglein 1 and its direct proteolysis by Staphylococcus hyicus exfoliative toxins isolated from pigs with exudative epidermitis. Veterinary Dermatology, v. 16, n. 5, p. 315323, 2005.

OLIVEIRA, V. C.; MELLO, R. P.; D’ALMEIDA, J. M. Dípteros muscóides como vetor mecânico de ovos de helmintos em jardim zoológico, Brasil. Revista de Saúde Pública, v. 36, n. 5, p. 614-620, 2002.

PHILPOOT, M.; EZEH, A. O. The experimental transmission by Musca and Stomoxys species of $D$. congolensis infection between cattle. British Veterinary Journal, v. 134, n. 6, p. 515-520, 1978.

PIRES, S. D.; CASTRO, B. G.; BITTENCOURT, A. J. Regiões do corpo de eqüinos preferidas para alimentação por Stomoxys calcitrans. Revista Universidade Rural, Série Ciências da Vida, v. 23, supl. 1, p. 299-300, 2003.

SCHLEIFER, K. H.; KILLPER-BALZ, R.; DEVRIESE, L. A. Staphylococcus arlettae sp. nov., S. equorum sp. nov., and S. kloosii sp. nov.: three new coagulase-negative, novobiocin resistant species from animals. Systematic Applied Microbiology, v. 5, n.4, p. 501-509, 1984.

SCHOFIELD, S.; TORR, S. J. A comparison of the feeding behavior of tsetse and stable flies. Medical and Veterinary Entomology, v. 16, n.2, p. 177-185, 2002.

Received on March 02, 2007.

Accepted for publication on November 21, 2007. 